DOI: https://doi.org/10.47405/mjssh.v6i12.1201

\begin{tabular}{|c|c|}
\hline 4 & Malaysian Journal of Social Sciences and Humanities (MJSSH) \\
\hline 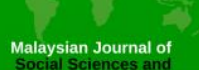 & Volume 6, Issue 12, December 2021 \\
\hline (MJ-sSH) & e-ISSN : 2504-8562 \\
\hline & $\begin{array}{l}\text { Journal home page: } \\
\text { www.msocialsciences.com }\end{array}$ \\
\hline
\end{tabular}

\title{
Understanding the Sociological Aspects Impacting the Business Endeavour Among Bumiputera Graduates
}

\author{
Nur Liyana Yasmin Mohd Razalli' ${ }^{1}$, Mohd Ali Bahari Abdul Kadir ${ }^{2}$ \\ ${ }^{1}$ Faculty of Business and Management, Universiti Teknologi MARA, Shah Alam, Malaysia \\ ${ }^{2}$ Faculty of Business and Management, Universiti Teknologi MARA, Puncak Alam, Malaysia \\ Correspondence: Nur Liyana Yasmin Mohd Razalli (nurliyanayasmin@gmail.com)
}

\begin{abstract}
In 2020, 202,400 from 5.36 million graduates in Malaysia were unemployed. Although the unemployment may have happened mainly because of the COVID-19 pandemic and various Movement Control Order (MCO), 16,000 of them were already unemployed for more than a year. The situation has raised a question as to why they did not become entrepreneurs. Hence, the researcher interviewed seven Bumiputera graduate entrepreneurs to understand the sociological aspects impacting the business endeavours among the graduates. The sampling techniques used were purposive and snowball sampling techniques. The researcher found that the ultimate reason for getting into universities is to be employed, not to do business. Bumiputera also does not have entrepreneurial culture. Instead, they have a culture of working for others. Although most participants were aware that social status is important for social networks that are crucial for business development, some thought that it is not essential for them because they only want to do business just to survive. Their past working experience also played a vital role in leading them to become entrepreneurs.
\end{abstract}

Keywords: Bumiputera, graduate, entrepreneurs

\section{Introduction}

Entrepreneurship offers excellent advantages such as creating new markets, facilitating economic development, and solving unemployment issues (Dragan et al., 2013; L. Hamilton \& Klerk, 2016; Marzuki et al., 2016; Muhammad, 2017). Hence it is not surprising that The Ministry of Education Malaysia (MoE) aims to produce graduates with an entrepreneurial mindset and the drive to create employment opportunities (Ministry of Education Malaysia, 2019). However, in 2020, 202,400 from 5.36 million graduates in Malaysia were unemployed, and 23,500 of them were unemployed for six to twelve months (Department of Statistics Malaysia, 2021a). Although understandably, the unemployment may have happened mainly because of the COVID-19 pandemic and various Movement Control Order (MCO), 16,000 of them were already unemployed for more than a year (Department of Statistics Malaysia, 2021a), instead of becoming entrepreneurs.

It would be even more challenging for the government to encourage more entrepreneurial activities among the educated Bumiputera because entrepreneurship itself also appears to be not the desired career choice among the Bumiputera. In 2019, the Bumiputera owned only $40 \%$ of almost one million companies registered under Suruhanjaya Syarikat Malaysia (SSM). Former Deputy Minister of Entrepreneur Development Datuk Wira Mohd Hatta attributed the situation to the Bumiputera overt 
dependency on the government (Bernama, 2019). Although the truth hurts, this is the fact that one should not deny. Bumiputera receives special privileges such as legislated economic subsidies, education scholarships and job training programmes (Floyd, 2019). Even more, during the COVID-19 pandemic, RM67.5 million was allocated just for the 340 SME owners whose applications were approved (Department of Statistics Malaysia, 2021b). Sadly, the growth of Bumiputera entrepreneurial activity are still unable to cope with the pace of the nation's overall development. The government's efforts could not boost an entrepreneurial culture, nor help them enhance entrepreneurial competitiveness and achievement (F. Abdullah et al., 2009; Hamidon, 2009).

Recently, Datuk Seri Tajuddin Abdul Rahman of the political party Barisan Nasional-Pasir Salak voiced his opinion. He suggested that the government should provide improved strategies to develop the Bumiputera's economy instead of focusing on welfare assistance (Yunus \& Yusof, 2021). Indeed, it is crucial to take a step back and think from a different point of view that economists tend to neglect, such as the sociological perspectives. Sociology could provide intellectual values in entrepreneurship. It provides a better understanding of human society and how the social system work. Apart from that, a comparative study of human societies even allows one to understand that people in different societies have many ways to earn a living (Mondal, 2017). This paper discusses the findings from interviews with seven Bumiputera graduate entrepreneurs in the Klang Valley.

\section{Literature Review}

The sociological theory is the third vital entrepreneurship theory (Simpeh, 2011). However, although sociology could provide intellectual values in entrepreneurship through the understanding of the human society and the social system, the economists tend to disregard the sociological perspectives (R. T. Hamilton \& Harper, 1994; Mondal, 2017). Hence, it becomes a plausible reason why the government's efforts to increase entrepreneurial activities mainly involve financial assistance. Many strategies are made available to identify and predict who might want to become entrepreneurs. McClelland's Need for Achievement (NAch), for instance, undoubtedly has reliable measurement. However, it is not helpful to predict major career decisions because entrepreneurial activities will still not happen if there are no opportunities for business endeavours. Instead, the sociological background makes entrepreneurial activities more predictable, even though not everyone with the same characteristics wants to become an entrepreneur (Reynolds, 1992).

Furthermore, in entrepreneurship studies, the sociological perspectives are different from psychological and economic perspectives. First, instead of analysing the entrepreneurs, it concentrates on the interpersonal networks, organisational structure, population, field-level processes, and broader institutional environments. Second, it focuses on the symbolic and cultural aspects of business activities instead of the material aspects of business start-ups like market conditions and financing. Lastly, it seeks to understand entrepreneurship in different contexts and business fields (Ruef \& Lounsbury, 2007). Four social contexts offer the opportunity for entrepreneurship: social networks, life course stage context, ethnic identification, and work experiences (Reynolds, 1992).

\section{Social Networks (and Social Status)}

Entrepreneurs need to create, maintain, and grow their social networks because social networks allow them to gain trust. Gaining trust from others can increase the legitimacy of entrepreneurs and the standings of their businesses, hence assisting them to become successful entrepreneurs (Mansor \& Daud, 2020; Reynolds, 1992). Through social networks, entrepreneurs can get essential resources, overcome obstacles, gain support, widen their knowledge about the available opportunities, explore new options to enhance performance, and gain competitiveness in the markets (Mansor \& Daud, 2020). However, they must have social status first. Past literature has revealed that the size and reach of people's social networks tend to be positively related to their social status (Cao \& Smith, 2021).

In modern society, it shifts towards a greater weight on work as a marker of the individual's identity and has a significant bearing on social status (Reneflot \& Evensen, 2014). However, it depends on the 
attitudes of the majority population. For instance, Wahlbeck (2008) found that Turkish entrepreneurs residing in Finland noted they have a good social status precisely because they are entrepreneurs. It also depends on the hard effort and income level (Van Praag, 2009). An individual with a higher income has more opportunities to achieve what they want. It enables the individual to buy more material goods and services, besides having a higher status in society. Many economists in the past have observed that individuals compare themselves to other individuals with respect to income, consumption, status, or utility (Frey \& Stutzer, 2002).

Furthermore, it depends on the level of education. Through education, the individual has high status and high economic returns (Posselt \& Grodsky, 2017). One of the critical factors of the perceived status of occupation is education. In a study conducted in the Netherlands, $76 \%$ of the research participants who are Dutch students rated that the education level required is the most attached standard for status and the most significant contributing factor of the status of occupations (Van Praag, 2009).

\section{Life Course Stage Context}

The life course stage also impacts the opportunities for entrepreneurial activities. A community's expectations and standards define the society. These expectations and standards set what is acceptable and not acceptable in society (Davis, 2019). The life course provides a cultural framework for allocating individuals to social roles and orientation for individual life plans. Employment is one of the age-related achievements which is unavoidable (Heinz, 2010). The University of Minnesota (n.d.) noted that adults aged 18 to 64 years old tend to oblige to these standards. Even in Malaysia, the working age is 15 to 64 years old (Department of Statistics Malaysia, 2021c).

In the context of this paper, social norms, parents, and others play an essential role in developing young people's expectations for their future (Millar, 2014). For decades, education has been known as the door to success, and it is synonymous with development. At a higher education level, the growth of educated individuals is at both personal and professional levels (Jacobs, 2017). When the students graduate, society assumes these graduates can effortlessly get employment opportunities with fixed income and fill in the key positions in any organisation because they are supposed to be more competent than those with lower academics (Z. Abdullah, 2018; Bartos et al., 2015). Hence, it is not surprising if the graduates are not interested in becoming entrepreneurs because there is a doctrine that they need to get employment opportunities after completing their studies.

\section{Ethnic Identification}

Ethnic is a race, common culture, or both, depending on the country. Individuals from different countries perceive and describe the term differently (Hamer et al., 2020). The individual's sociological background can determine whether the individual will become an entrepreneur. For instance, marginalised groups could break all difficulties and try to gain success, motivated by their deprived background to attain better life (Reynolds, 1992). Sabuhilaki (2016) found that socio-cultural norms affect the degree of the acceptableness of entrepreneurial activities among the members of society. First, if the social norms encourage personal judgment on making decisions, it will increase the rate of entrepreneurial activities. Second, the social norms affect the number of individuals who are prepared to get involved in the activities to make an example of entrepreneurship. Third, specific cultural beliefs are affecting encouraging entrepreneurial activities.

The Bumiputra, which refers to the Malays, natives of Sabah and Sarawak, and other ethnic groups who do not fall under Article 153 (Johan, 2017), receive special privileges such as legislated economic subsidies, education scholarships, and job training programs (Floyd, 2019). However, they lack entrepreneurial culture (Hamidon, 2009). The government's initiatives became fruitless in narrowing the economic gaps between Bumiputera and non-Bumiputera. Moreover, the government's efforts do not help boost an entrepreneurial culture, nor do they help enhance entrepreneurial competitiveness and achievement (F. Abdullah et al., 2009; Hamidon, 2009). They have negative attitudes and mindsets. There is a lack of entrepreneurship culture, including among the educated Bumiputera society. Even 
the parents prefer their children to become civil servants instead of entrepreneurs (Hamidon, 2009). The objective of having a 30\% Bumiputera equity stake is still a long way from the target (Arshad et al., 2018).

\section{Work Experiences}

Work experience is said to have strong relation with entrepreneurship (Colombatto \& Melnik, 2007). Although not statistically significant, Fatoki (2014) found that individuals with working experience have a higher entrepreneurial intention level than those who do not. In general, they will become entrepreneurs because of the factors such as their actual intention of being employed, getting help for business start-ups, the reason to quit from employment, the need for working experience, related work experience, and role of past work experience (Khan et al., 2016). The individuals may be tired of corporate politics and not satisfied with their employment. Through entrepreneurship, they may have freedom, happiness, and quality of life balance. Achieving all these means they have achieved success (Minarcine \& Shaw, 2016). Besides that, through working experiences, the individuals may develop specific skills and may also help individuals gain knowledge about the industry and identify opportunities to create businesses (Olaechea, 2018).

Ismail et al. (2006) found that the type of experience from the former work does not significantly influence the individuals' decisions to start up their business. However, a more recent study showed that individuals with experience in management have a higher likelihood of new ventures (Xi et al., 2016). Moreover, individuals with a breadth of functional work experience may have new business ideas than those with deep industry work experience (Gabrielsson \& Politis, 2012). The individuals' earlier experience in full-time employment positively impacts the size of newly founded firms (Colombatto \& Melnik, 2007). It influences their business performances (Othman et al., 2009), especially those with managerial experience. The managerial experience can be one of the contributing factors for their business success (Staniewski, 2016).

\section{Methodology}

The researcher interviewed seven Bumiputera graduate entrepreneurs in Klang Valley. The researcher selected them using purposive and snowball sampling techniques. To ensure their anonymity, the researcher labelled them from P1 to P7. As shown in Table 1, seven of them were male. Five of them were between 20 to 29 years old, and four were between 40 to 49 years old. Only four of them were already married. Three of them had Diploma, and the other four had Bachelor's Degree as their highest qualification. Two of them were only in the service sector, and three were only in the trading sector. Meanwhile, the other two were in more than one business sector, including service, manufacturing, and trading.

Table 1: Demographics of Participants

\begin{tabular}{cccccc}
\hline Participant & Gender & Age & Marital Status & Qualification & Business Sector \\
\hline P1 & Male & $40-49$ & Married & Degree & Service, manufacturing, trading \\
P2 & Male & $20-29$ & Married & Diploma & Trading, service \\
P3 & Male & $20-29$ & Married & Degree & Service \\
P4 & Male & $20-29$ & Single & Diploma & Trading \\
P5 & Male & $20-29$ & Single & Degree & Trading \\
P6 & Male & $20-29$ & Single & Degree & Service \\
P7 & Male & $40-49$ & Married & Diploma & Trading \\
\hline
\end{tabular}

Source: Own

\section{Result}

The researcher found several themes from the interviews that could explain the sociological aspects impacting business endeavour among the Bumiputera graduates. 


\title{
Social Status for Business Success
}

The theme emerged when the researcher asked whether social status is important to them. Without any hesitation, P2 agreed that social status is vital in doing business, mainly because entrepreneurs need to establish themselves in the eyes of others, gain confidence from others, and inspire others.
"Like if we want to go far in this entrepreneurship field, we need to remain visible to the society's eyes. We must be smart being in society. Indeed it is important. Maybe it is hard if you [want] to do business and you are an introvert. You need to show who you are when you are doing business. Need to establish who you are...we need to show who we are once you become entrepreneurs to let people interested and have confidence in us and maybe what we do can give [inspiration] to others?"-P2

P1 and P7 echoed P2's opinion.However, although they were quite famous and often received attention from the media, they denied that social status is essential, especially in their lives. They noted that social status put restrictions on their lives.

\begin{abstract}
"No [not important] ... It is helpful, but the percentage is very little. It is more of not helpful. It is more of making us feel eh cannot that, cannot this. That is wrong, this is wrong...apparently, it is human nature that you must show the good things... Must show success, have to show your status then only people are interested, right? That is normal."-P1
\end{abstract}

"Not important because I like to make friends. So when there is a gap like that, for instance, when already successful, afraid of forgetting yourself...Apparently, if we look at the business side, it is important. The part of expanding the business. When I know many people, and I went to many events, there is customer trust."-P7

P4 and P5, partners in a small business, also admitted that social status is essential to have a social network and expand businesses. However, they thought that social status was unimportant because they were not planning to expand the business. It was enough for them just to survive.

"Maybe it is important if it is for survival. Maybe people are chasing after it. Actually, this social position, maybe in general, people are chasing after that thing [social status]...Maybe people are chasing that thing for networking. The bigger [network], the bigger his business...However, as for me, it is not even necessary...Maybe do not need it yet."-P4

"For me, it is important. It depends on how far they want to influence. If they are indeed in a big business, they really need the influence. People say, networking...But for myself, not that important...not that we are [not] chasing after it, just it is not the time yet. If got it, Alhamdulillah. Can be one of the ways [to] increase popularity, people know [us]."-P5

\section{The Culture of Getting Into Universities and Getting Employed}

The theme emerged when the researcher asked them their reasons or why other people get into universities. The Bumiputera graduates noted that people get into universities because the society, especially the parents, has brainwashed them that getting into universities is mandatory to get good employment opportunities with a high salaries.

"Template- Get into university, get a degree, get a diploma, easy to get a job, big salary. That is the first mindset."-P1 
"...taught by our parents, by the society surrounding that if you want to succeed you really must go through the steps. Some of the steps that we must go through are we have to further studies to a higher or a better level."-P2

"They expected me to get a job after finished studying...They want a government job, government job, government job."-P3

"...maybe it is a culture. After taking SPM, parents want to see us further our studies."-P4

"...parents have taught us that we will get a good job if we have higher education."P5

"... It is kind of like a culture since everyone, everybody is talking about going to college, so people just go to college for the sake of going to college... So when I am practically the one who really studied to graduate, to work, to get a good job, so of course there is that expectation. To have a stable income, a secured job, that expectation was there."-P6

\section{The 'Bumiputera Have to Work' Culture}

The theme emerged when the researcher asked the reason why not many graduates are interested in becoming entrepreneurs. P1, and P2 noted that not many Bumiputera graduates are interested in becoming entrepreneurs because Bumiputera has a non-entrepreneurial culture. Instead, the Bumiputera prefers to work because work can guarantee the future, even just as an office boy.

"...our culture is not an entrepreneurial culture. Our culture is the culture from the past which you have to first study the highest, you become an office boy is alreadymy dad's time, you worked [for] the government, office boy, was okay. Already awesome because you [have] fixed salary. Ha this is the problem. The mindset problem when we put fixed salary [means], easy, easy, easy. Added with Bumiputera special rights.".-P1

"...So since from the ancestors, it is already said "You want a good job you need to go study, and then you get a job in the government. In the government can guarantee the future or find a good job". Our grandparents continue it. Continued by our parents...our Malay people really think that study well, get a good job, that is your written future. You cannot do anything. You only need to work. All Malay people need to work...our Malay people think that working in the government really guarantees the future."-P2

P3 added that the Bumiputera, specifically the Malays, only know to wait for salary every month. They also only want glamourous occupations. Even if they decide to do business, they want a glamourous one.

\footnotetext{
"Because our Malays [only] know, go to the office, receive the salary on the 25th day of the month...Sometimes our people are fond of glamour. Our Malays...They will not want the job if it is not glamourous. So if I want to do business, I want a glamourous business."-P3
}

\section{Work Experience Leading to Business Endeavour}

The theme emerged when the researcher asked the reason why they started doing their businesses. P1, P3, and P7 noted that prior working experience had led them to become entrepreneurs. Mainly because they were bored with their work, did not have the passion, and wanted to work with freedom. 
"...I was eager to explore myself further. And I thought at ****, the place I worked, it did not expand my ideas. Meaning I was working in a very high bureaucracy... So the work got slow... So I said, "I have to chow [go]. I have to go."-P1

"...After learning marketing, I stayed at the credit department. The credit department is the back office. Just to share my experience, I just stayed keying in cases before this but it didn't match my soul...this is not my passion... that is when [I] did sales...Went out making sales, it was fun. After that, already enjoyed, already gained knowledge about loans then only went out selling houses. Only then sell houses. That's why I simply felt confident [to leave the job and start doing business]".-P3

"...Actually [I] have always loved doing business. [After] completing SPM, I already sold coconut water while working in factories. The income was just like that. So I was able to estimate. Then, before starting searching, that time already worked as a nurse, then I resigned in year 2013. Then I was at a private [hospital], the workload was lesser. So it got more boring...I thought about finding a business."-P7

\section{Discussion}

The interviews with the seven Bumiputera graduate entrepreneurs showed that sociological factors could have an impact on Bumiputera graduate entrepreneurs' business endeavour.

The present qualitative study could not determine whether individuals with previous work experience have higher entrepreneurial intention, as Fatoki (2014) suggested. However, the researcher found that work experience itself may be the reason for business start-ups, similar to the findings by Minarcine \& Shaw ( 2016) and Khan et al. (2016). Some of the research participants who have worked before felt unhappy and bored with their employment, leading them to become entrepreneurs to pursue their passion and earn more. Besides, they were tired of bureaucratic organisation. Becoming entrepreneurs allow them to work and express their creativity freely. Not just that, as Colombatto \& Melnik (2007) noted, their work experiences may be beneficial in their business endeavours. Their work experience helped them to perform well in their businesses (Othman et al., 2009). The participants with working experience were aiming to go big in their businesses, and not just for the sake of putting food on the table.

Indeed, the individual's sociological background can determine whether the individual will become an entrepreneur (Reynolds, 1992). The Bumiputera has a working culture instead of entrepreneurial culture. The participants even noted that getting into universities is like a 'template' in life. It is an inevitable culture and life course stage. The individuals have to complete the Sijil Pelajaran Malaysia (SPM), get into universities, and get employed. Similar to the findings by Hamidon (2009), society, especially the parents, expects their children to work after completing their studies because it can guarantee the future. Employment is one of the age-related achievements which is unavoidable (Heinz, 2010). The expectations and standards set what is acceptable and unacceptable in society (Davis, 2019). As someone belonging to a society, their ultimate duty is to fulfil the expectations and not deviate from the norm. Socio-cultural norms affect the degree of the acceptableness of entrepreneurial activities among the members of society (Sabuhilaki, 2016). Hence, it is not surprising why not many Bumiputera and the graduates are not interested in becoming entrepreneurs, and this remains an issue to be solved.

As Mansor \& Daud (2020) and Reynolds (1992) noted, most present research participants understood the importance of social status. Social status is essential to have social networks that can be beneficial in businesses. Social status can affect individuals' social networks in terms of size and reach (Cao \& Smith, 2021). Moreover, through social networks, entrepreneurs can get essential resources, overcome obstacles, gain support, widen their knowledge about the available opportunities, explore new options to enhance performance, and gain competitiveness in the markets (Mansor \& Daud, 2020). However, some participants thought that social status is unnecessary because they do not intend to expand their 
businesses yet. It is safe to say that rejecting social status means that they lack social networks and do not have the perks of having social networks. Hence, it can be one of the reasons why the growth of Bumiputera's entrepreneurial activity seems to be unable to cope with the pace of the nation's overall development (F. Abdullah et al., 2009).

\section{Conclusion}

In a nutshell, sociological factors can impact the Bumiputera graduates' business endeavours. Getting into universities is not just culture in the society, but it is like a necessary life course stage of individuals belonging to Bumiputera society. Getting into universities means they have to be employed. Doing business is not their ultimate reason. Being part of society, the Bumiputera graduates are bound to society's standards and expectations, especially their parents. Not just that, believing social status is not essential for them may lead to a slow-growth business because they lack social networks that are beneficial for the growth of their businesses. Instead of spoon-feeding the Bumiputera graduates with more financial assistance and more training programmes to attract them to become one, it would be wiser for the government to take the initiative in understanding the Bumiputera's sociological background and change the society's mindset first.

\section{References}

Abdullah, F., Hamali, J., Deen, A. R., Saban, G., \& Abdurahman, A. Z. A. (2009). Developing a Framework of Success of Bumiputera Entrepreneurs. Journal of Enterprising Communities: People and Places in the Global Economy, 3(1), 8-24.

Abdullah, Z. (2018). Exploring University Branding: Employers' Expectation On University Graduates On Competency. Jurnal Personalia Pelajar 21(1): 95-104 95, 21(1), 95-104.

Arshad, A. S., Zain, Z. M., Rashid, A. A., Arshad, A. A., Ariffin, A., Mokhtar, M., \& Zahari, A. S. (2018). Entrepreneurial Orientation towards Business Performance: A Study on Tunas Mekar Participants. ASEAN Entrepreneurship Journal (AEJ), 4(1), 25-35.

Bartos, P., Rahman, A., Horak, J., \& Jacova, H. (2015). Education and Entrepreneurship in The SME Segment in Economic Transformation. Economics and Sociology, 8(2), 227-239.

Bernama. (2019). Only 40pct of Companies are Owned by Malays, Other Bumis - Hatta. Malaysiakini. https://www.malaysiakini.com/news/482933

Cao, J., \& Smith, E. B. (2021). Why Do High-status People Have Larger Social Networks? Belief in Status-quality Coupling as a Driver of Network-broadening Behavior and Social Network Size. Organization Science, 32(1), 1-22.

Colombatto, E., \& Melnik, A. (2007). Early Work Experience and the Transition into Entrepreneurship. Journal of Entrepreneurial Finance, 12(1), 9-26.

Davis, A. (2019). Societal Expectations for a College Student. The Aumnibus. http://theaumnibus.com/societal-expectations-for-a-college-student/

Department of Statistics Malaysia. (2021a). Graduates Statistics 2020. https://dosm.gov.my/v1/index.php?r=column/cthemeByCat\&cat=476\&bul_id=U11tVWpwNXRN RUR2NlhRSHZmenRMUT09\&menu_id=Tm8zcnRjdVRNWWlpWjRlbmtlaDk1UT09

Department of Statistics Malaysia. (2021b). Key Statistics of Labour Force in Malaysia, September 2021.

https://www.dosm.gov.my/v1/index.php?r=column/cthemeByCat\&cat=124\&bul_id=NXhZL3c1

UmZ6OHM2Z2grTzlTN0hGQT09\&menu_id=Tm8zcnRjdVRNWWlpWjRlbmtlaDk1UT09

Department of Statistics Malaysia. (2021c). Press Release: Current Population Estimates, Malaysia, 2021.

https://www.dosm.gov.my/v1/index.php?r=column/pdfPrev\&id=ZjJOSnpJR21sQWVUcUp6OD Rudm5JZz09

Dragan, C., Dejan, D., Srdjan, B., Dragana, S., \& Robert, M. (2013). Quality of Business, Entrepreneurship Education and Business start up Intentions Among Students in Serbia: Research Results. Industrija, 41(3), 125-145.

Fatoki, O. (2014). The Entrepreneurial Intention of Undergraduate Students in South Africa: The 
Influences of Entrepreneurship Education and Previous Work Experience. Mediterranean Journal of Social Sciences, 5(7), 294-299.

Floyd, C. W. (2019). Sons of The Soil: The Past, Present, and Future of Malaysia's Bumiputera. Perspectives on Business and Economics, 37-, 97-104.

Frey, B. S., \& Stutzer, A. (2002). What Can Economists Learn from Happiness Research ? Journal of Economic Literature, XL(June), 402-435.

Gabrielsson, J., \& Politis, D. (2012). Work Experience and The Generation of New Business Ideas Among Entrepreneurs: An Integrated Learning Framework. International Journal of Entrepreneurial Behaviour and Research, 18(1), 48-74.

Hamer, K., McFarland, S., Czarnecka, B., Golińska, A., Cadena, L. M., Łużniak-Piecha, M., \& Jułkowski, T. (2020). What Is an "Ethnic Group" in Ordinary People's Eyes? Different Ways of Understanding It Among American, British, Mexican, and Polish Respondents. Cross-Cultural Research, 54(1), 28-72.

Hamidon, S. (2009). The Development of Malay Entrepreneurship in Malaysia. Massey University.

Hamilton, L., \& Klerk, N. de. (2016). Generation Y Female Students' Motivation Towards Entrepreneurship. International Journal of Business and Management Studies, 8(2), 50-65.

Hamilton, R. T., \& Harper, D. A. (1994). The Entrepreneur in Theory and Practice. Journal of Economic Studies, 21(6), 3-18.

Heinz, W. R. (2010). Life Course Dynamics in Historical Development and Theoretical Approaches in Sociology. In C. Crothers (Ed.), Encyclopedia of Life Support Systems (Vol. 1).

Ismail, A. Z. H., Zain, M. F. M., \& Ahmed, E. M. (2006). A Study Of Motivation In Business Start-Ups Among Malay Entrepreneurs. International Business \& Economics Research Journal, 5(2), 103112.

Jacobs, K. (2017). The Rise of the Unemployed Graduates: Who/What is to Blame? CA Global. https://www.caglobalint.com/recruitmentafrica/blog/2017/09/19/the-rise-of-the-unemployedgraduate-whowhat-is-to-blame/

Johan, S. (2017). What Defines a Bumiputra? The Star Online. https://www.thestar.com.my/opinion/online-exclusive/a-humble-submission/2017/07/27/whatdefines-a-bumiputra-as-we-debate-this-issue-it-is-important-for-us-to-get-all-the-terminology-r

Khan, S. M., Rehman, M., \& Rehman, C. A. (2016). Work Experience and Entrepreneurship: Evidence From Various Industries of (Lahore) Pakistan. Sci.Int.(Lahore), 28(1), 571-583.

Mansor, T. R. T., \& Daud, Z. (2020). The Effect of Social Network on Malaysian Malay-Owned SME Performance. Albukhary Social Business Journal, 1(1), 73-85.

Marzuki, S. Z. S., Kadir, M. A. B., Buyong, S. Z., \& Junid, J. (2016). Motivating Factors Influencing Business among Youth in Malaysia. ASEAN Entrepreneurship Journal, 2(2), 37-45.

Millar, E. (2014). The Expectation Gap: Students' and Universities' Roles in Preparing for Life After Grad. In The Globe and Mail. https://www.theglobeandmail.com/news/national/education/theexpectation-gap-students-and-universities-roles-in-preparing-for-life-after-grad/article21187004/

Minarcine, S., \& Shaw, C. (2016). Motivations for Entrepreneurship. International Journal of the Academic Business World, 10(2), 47-56.

Ministry of Education Malaysia. (2019). Laporan Kajian Pengesanan Graduan 2018.

Mondal, P. (2017). The Importance of Sociology to Society. https://www.yourarticlelibrary.com/sociology/the-importance-of-sociology-to-society-1219words $/ 8490$

Muhammad, Y. (2017). The Solution to Unemployment? Universal Entrepreneurship. LinkedIn. https://www.linkedin.com/pulse/solution-unemployment-universal-entrepreneurship-muhammadyunus

Olaechea, A. B. (2018). Working Experience and Entrepreneurship. Universidad Esan.

Othman, N. H., Pazil, A. H. M., Attaullah, S. A., Zaib, S. Z. M., Jin, C. W., \& Mahadi, N. F. D. (2009). Influence of Work Experience and Education Towards Business Performance Among Entrepreneurs. International Business, 1(2016), 78-87.

Posselt, J. R., \& Grodsky, E. (2017). Graduate Education and Social Stratification. Annual Review of Sociology, 43(1), 353-378.

Reneflot, A., \& Evensen, M. (2014). Unemployment and Psychological Distress Among Young Adults in The Nordic Countries: A Review of The Literature. International Journal of Social Welfare, 23(1), 3-15. 
Reynolds, P. D. (1992). Sociology and Entrepreneurship: Concepts and Contributions. Entrepreneurship Theory and Practice, 16(2), 47-70.

Ruef, M., \& Lounsbury, M. (2007). Introduction: The Sociology of Entrepreneurship. Research in the Sociology of Organizations, 25, 1-29.

Sabuhilaki, B. (2016). Social Factors Affecting Entrepreneurship and Youth Employment. International Journal of Humanities and Cultural Studies, 3(1), 1226-1236.

Simpeh, K. N. (2011). Entrepreneurship theories and Empirical research: A Summary Review of the Literature. European Journal Of Business and Management, 3(6), 1-8.

Staniewski, M. W. (2016). The Contribution of Business Experience and Knowledge to Successful Entrepreneurship. Journal of Business Research, 69(11), 5147-5152.

University of Minnesota. (n.d.). 4 . 4 Socialization Through the Life Course. Retrieved July 22, 2021, from https://open.lib.umn.edu/sociology/chapter/4-4-socialization-through-the-life-course/

Van Praag, M. (2009). Who Values The Status of The Entrepreneur? In IZA Discussion Papers (No. 4245).

Wahlbeck, Ö. (2008). Entrepreneurship as Social Status: Turkish Immigrants' Experiences of SelfEmployment in Finland. Migration Letters, 5(1), 53-62.

Xi, G., Block, J., Lasch, F., Robert, F., \& Thurik, R. (2016). Work Experience from Paid Employment and Entry Mode to Entrepreneurship: Business Takeover Versus New Venture Start-up. In IZA Discussion Papers (No. 9949).

Yunus, A., \& Yusof, T. A. (2021). Stop Blaming the Bumiputera, Says Tajuddin [NSTTV]. New Straits Time. https://www.nst.com.my/news/nation/2021/11/742369/stop-blaming-bumiputera-saystajuddin-nsttv 